\title{
Kajian Pengaruh Material Graphene pada kinerja Biosensor Berbasis Surface Plasmon Resonance (SPR) pada Deteksi Makanan Halal sebagai Pendukung Halal Research Center UIN Sunan Kalijaga Yogyakarta
}

\author{
Wida Yanti ${ }^{*}$, Asih Melati \\ Prodi Fisika dan Pendidikan Fisika, Fakultas Saintek UIN Sunan Kalijaga Yogyakarta \\ Jl. Marsda Adisucipto No. 1 Yogyakarta \\ *email : salma_wida@yahoo.com
}

ABSTRACT

In this paper, a graphene was applied as an active material in the Surface Plasmon Resonance (SPR)based biosensor for porchine gelatin detection in the wavelength $632.8 \mathrm{~nm}$. Comparing with the konvensional SPR, from the simulation, we obtain the enhancement sensitivity of existence of the porchine gelatin due to the involvement of graphene. The system consist of five layers material i.e prisma/Ag/graphene/porchine gelatin/air in the Kretscmann configuration. The reflectivity spektrum depends on the refractive index and the thickness of each layer. In this simulatin, refractive index of the prism BK7 is $1.51, \mathrm{Ag}$ is $0.13455+3,98651 i$ with the thickness $40 \mathrm{~nm}$, graphene is $2.5748+1.4935 i$ and gelatin is $1.383+0.1243 i$. Our result shows that the peak of reflectivity is shifted to different angle of incident light and the enhancement of the sensitivity is $2.86 \%$.

Keyword: Surface Plasmon Resonance (SPR), Porchine Gelatin, Graphene, ATR

\section{ABSTRAK}

Pada penelitian ini, material graphene diaplikasikan sebagai bahan aktif pada biosensor berbasis Surface Plasmon Resonance (SPR) untuk mendeteksi gelatin babi pada panjang gelombang $632.8 \mathrm{~nm}$. Melalui simulasi, telah diperoleh peningkatan sensitivitas pendeteksian keberadaan gelatin babi dengan keterlibatan graphene dibandingkan dengan tanpa keterlibatan graphene. Sistem SPR dengan konfigurasi Kretschmann terdiri dari lima lapisan yaitu Prisma/Ag/graphene/gelatin babi/udara. Parameter indeks bias dan ketebalan masing-masing lapisan berpengaruh terhadap reflektivitas yang dihasilkan. Pada sistem ini indeks bias prisma BK7 adalah 1.51, indeks bias lapisan tipis Ag adalah $0.13455+3,98651 i$ dengan ketebalan $40 \mathrm{~nm}$, indeks bias graphene adalah $2.5748+1.4935 i$ serta gelatin babi adalah $1.383+0.1243 i$. Hasil perhitungan dan simulasi menunjukkan adanya pergeseran dip pada kurva SPR atau kurva reflektansi yang menghasilkan peningkatan sensitivitas sebesar $2.86 \%$ dibandingkan dengan kurva SPR konvensional (tanpa keterlibatan graphene).

Kata kunci: Surface Plasmon Resonance (SPR), Gelatin Babi, Graphene, ATR.

\section{PENDAHULUAN}

Kehalalan suatu produk saat ini menjadi perhatian besar di kalangan masyarakat, terutama di Indonesia yang mayoritas penduduknya muslim terutama obat dan makanan. Berdasarkan Journal Halal (Kuala Lumpur), dalam 10 tahun terakhir ini pasar makanan 
halal dunia sudah bernilai sekitar 632 miliar dolar per tahunnya. Malaysia juga akan mendirikan pabrik pembuat kapsul berdasar bahan gelatin halal ${ }^{[1]}$. Tidak hanya produk makanan, industri lainnya seperti keuangan, berbagai produk jasa, kosmetik, hotel, pakaian, asuransi sudah beramai-ramai berhijrah ke sesuatu yang terjamin kehalalannya. Sejumlah perusahaan multinasional non-muslim menerobos peluang pasar halal ketika melihatnya begitu menggiurkan. Pemerintah Asia dan Timur Tengah juga telah memposisikan diri sebagai pusat industri halal. Bahkan Belanda pun turut berperan dalam industri halal. Indonesia yang mempunyai penduduk mayoritas muslim memang sudah selayaknya turut berperan dalam mengembangkan pasar halal. Bukan hanya sekedar untuk menunjukkan eksistensi negara dan turut mengambil peluang pasar, tapi lebih difokuskan untuk melindungi penduduknya dari mengkonsumsi sesuatu yang haram. Oleh karena itu Indonesia harus bisa menjamin kehalalan produk-produk industri dalam negeri dan menjamin kehalalan produk-produk yang diimpornya dari luar negeri. Berkaitan dengan hal tersebut, salah satu tantangan dalam penjaminan kehalalan produk adalah adanya pemakain gelatin untuk bahan tambahan pada produk industri baik pada makanan, obatobatan, dan kosmetik. Hal ini karena, berdasarkan Harian Republika pada tahun 2009 lalu ${ }^{[2]}$, Indonesia masih 100\% mengimpor gelatin dari berbagai negara seperti Cina, Australia dan beberapa negara di Eropa. Padahal sekitar 50\% dari produksi gelatin dunia menggunakan kulit babi. Berdasarkan data Badan Pusat Statistik (BPS) perkembangan impor gelatin 3 tahun terakhir cenderung meningkat, baik dalam bentuk gelatin murni, turunan dari gelatin dan dalam bentuk kapsul untuk produk farmasi.

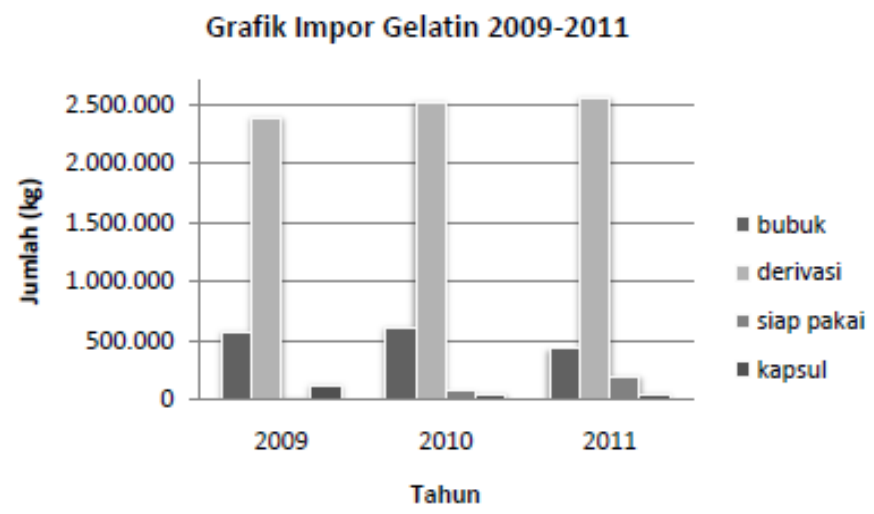

Gambar 1. (color online) Grafik Impor Gelatin 2009-2011

Badan yang berwenang mengeluarkan sertifikat halal untuk saat ini di Indonesia adalah LPPOM-MUI. Salah satu upaya mendukung ketersediaan bahan makanan dan obat halal di Indonesia tersebut, sangat perlu dikembangkan teknologi deteksi bahan makanan dan obat yang kemungkinan mengandung unsur bahan haram yang memiliki sensitivitas yang tinggi terutama untuk konsentrasi bahan yang rendah. UIN Sunan Kalijaga sebagai Universitas Islam juga sangat diharapkan mampu menjadi pelopor dan pendukung Program Pangan Halal salah satunya adalah optimalisasi Halal Research melalui pengembangan biosensor berbasis SPR yang mampu mengidentifikasikan sampai tingkat DNA gelatin babi dengan menggunakan sifat optisnya.

Berkaitan dengan perkembangan teknologi biosensor, salah satu yang unggul adalah biosensor optis. Pada tiga dekade terakhir ini, dalam dunia riset fisika berkembang biosensor optis berbasis SPR (Surface Plasmon Resonance) ${ }^{[3]}$. Secara fisika fenomena SPR adalah sebuah metode untuk mengkaji karakteristik bahan dengan cara mengenakan 
cahaya terpolarisasi (laser) pada permukaan bahan melalui prisma. Surface plasmon (SP) adalah gelombang osilasi elektron bebas yang merambat pada antar muka dua medium yaitu logam dan dielektrik. Saat cahaya terpolarisasi- $p$ yang merambat melalui prisma dan mencapai antar muka prisma-logam dengan sudut datang melebihi sudut kritis, atau dengan kata lain terjadi Attenuated Total Reflection (ATR), pada antarmuka keduanya muncul gelombang yang meluruh secara eksponensial pada arah tegak lurus antarmuka prisma-logam atau disebut sebagai gelombang evanescent yang. Jika ketebalan logam kurang dari $100 \mathrm{~nm}$ (untuk cahaya datang dengan panjang gelombang cahaya tampak dan infra merah) maka gelombang evanescent tersebut dapat berpenetrasi melewati logam dan terkopling dengan gelombang SP pada batas logam-dielektrik. Gelombang SP yang terbangkit pada antarmuka logam-dielektrik merambat sejajar arah rambat gelombang evanescent. Gelombang SP memiliki konstanta perambatan yang besarnya dipengaruhi oleh indeks bias udara/cairan di atasnya sementara besar konstanta perambatan gelombang evanescent dipengaruhi oleh sudut datang cahaya dan panjang gelombangnya. Fenomena ini ditunjukkan pada gambar 2. Kondisi dimana konstanta perambatan pada gelombang SP sama dengan konstanta perambatan pada gelombang evanescent disebut sebagai resonansi atau terjadi kopling yang dinyatakan sebagai

$$
K_{0} n_{p} \sin \theta_{S P R}=K\left(\frac{\varepsilon_{m} n_{\mathbb{d}}^{2}}{\varepsilon_{m}+n_{d}^{2}}\right)^{1 / 2}
$$

dengan $K_{0}$ adalah tetapan gelombang dari gelombang evanescent dengan sudut resonansi $\theta_{S P R}$ yang melalui prisma dengan indeks bias $n_{p}$. Sedangkan $K$ adalah tetapan gelombang SP dengan $\varepsilon_{m}$ adalah permitivitas $\operatorname{logam}$ serta $n_{d}$ adalah indeks bias dielektrik atau material yang dideteksi. Pada kondisi resonansi inilah berlangsung absorpsi cahaya maksimum yang berakibat munculnya besar reflektansi minimum. Sebelum prisma dilapisi oleh lapisan tipis logam, maka reflektansi akan mendekati nilai maksimum, sedangkan pada saat prisma telah dilapisi lapisan tipis logam maka akan terjadi reflektansi minimum pada sudut datang tertentu. Karena $K_{0}$ dipengaruhi oleh sudut datang dan $\mathrm{K}$ dipengaruhi oleh indeks bias dielektrik, maka pada saat terdapat perubahan indeks bias dielektrik, maka sudut SPR juga berubah nilainya. Kemudian perubahan sudut SPR dapat diamati melalui spektrum atau kurva reflektansi yang diukur denganmenvariasi sudut cahaya datang. Jika terdapat material yang ditempatkan pada permukaan logam maka indeks bias lapisan berubah, yang ditunjukkan oleh bergesernya posisi sudut SPR ke $\operatorname{kanan}^{[4]}$.

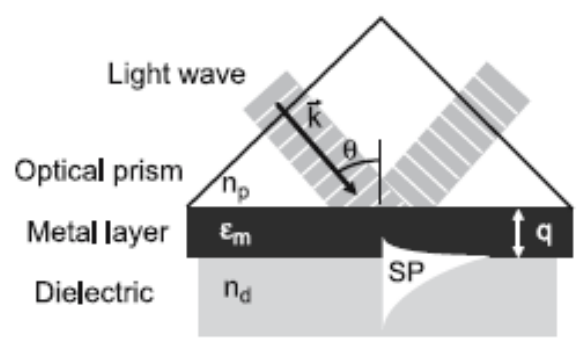

Gambar 2. (color online) Eksitasi Surface Plasmon (SP) pada ATR dengan konfigurasi Kretschmann 
Setiap material akan mempunyai karakteristik khusus ditinjau dari sifat optisnya salah satunya adalah parameter indeks bias material tersebut. Dengan dasar inilah metode SPR mempunyai sensitifitas yang sangat tinggi dalam mengenali jenis material, sekalipun material organik seperti gelatin babi. Selain itu, metode SPR ini tidak hanya dapat dilakukan pada permukaan lapisan tipis (thin film), namun juga dapat dikembangkan sebagai pendeteksi material dalam bentuk gas, padatan, maupun cairan. Melihat potensinya yang begitu besar, ke depannya teknologi sensor berbasis SPR dibutuhkan untuk deteksi dan analisis dari zat-zat kimia dan biokimia pada banyak bidang penting meliputi pengobatan, pemantauan lingkungan, bioteknologi, obat dan makanan. Pendeteksian zat-zat dan biomolekul tersebut sudah beberapa kali dilakukan, antara lain hibridisasi $\mathrm{DNA}^{[5]}$, membram protein ${ }^{[6]}$ dan darah manusia ${ }^{[7]}$ akan tetapi terdapat beberapa kelemahan pada biosensor konvensional antara lain terbatasnya pendeteksian untuk biomolekul dengan ukuran yang sangat kecil atau yang memiliki konsentrasi yang sangat rendah, serta adanya kurang kuatnya sinyal yang diperlukan untuk menunjukkan adanya kopling antara gelombang evanescent dengan gelombang SP sehingga pendeteksian tidak terjadi. Oleh karena itu dilakukanlah upaya untuk meningkatkan performa dari biosensor SPR ini yaitu antara lain dengan pemanbahan bahan aktif serta penguatan sinyal. Salah satu material yang dapat digunakan sebagai bahan aktif adalah graphene. Material Graphene adalah satu lembar karbon yang memiliki ketebalan satu atom dan memiliki ikatan atom karbon sp2. Struktur graphene berbentuk heksagonal seperti sarang lebah dan sangat stabil. Inilah yang membuatnya memiliki sifat-sifat unik hingga menarik minat para ilmuwan untuk mengembangkan aplikasinya dalam bidang teknologi. Sifat yang paling menarik adalah sifat elektrik graphene yang memiliki kemampuan membawa muatan yang besar dan memiliki mobilitas elektron yang tinggi pada suhu ruangan. Selain itu, graphene memiliki modulus Young yang besar pada sifat mekanik dan memiliki konduktansi termal yang tinggi pada sifat termalnya ${ }^{[8]}$. Pendeteksian material gelatin juga pernah dilakukan secara eksperimen yang hasilnya menunjukkan adanya pergeseran sudut SPR pada deteksi gelatin babi dan gelatin sapi pada kurva ATR. Besarnya pergeseran sudut SPR sebanding dengan besarnya indeks bias antarmuka antara perak dan gelatin ${ }^{[9]}$. Kemudian keterlibatan graphene pada sistem biosensor SPR juga dilakukan secara komputasi yaitu pada pendeteksian DNA ${ }^{[10]}$. Maka dari itu perlu dimulai penelitian dengan menggunakan SPR dengan keterlibatan bahan aktif seperti graphene dalam bidang penjaminan kehalalan produk industri baik produksi dalam negeri maupun produk impor. Perlu diselidiki apakah SPR mampu membedakan dua jenis gelatin dari sumber yang berbeda baik dari sumber maupun susunan asam aminonya.

Pada penelitian ini dilakukan kajian analitik dan komputasi terhadap model sistem SPR multi lapisan dalam konfigurasi Kretschmann ${ }^{[11]}$ dan mempelajari pengaruh penambahan lapisan tipis graphene terhadap peningkatan sensitivitas sistem SPR melalui kurva reflektansi. Sedangkan material yang akan dideteksi adalah gelatin babi.

\section{METODE}

Penelitian meliputi beberapa tahapan yaitu tahap perhitungan secara analitis nilai reflektansi, kemudian kurva ATR divisualisasikan secara grafis melalui komputasi dengan program MATLAB dan yang terakhir adalah perhitungan kenaikan sensitivitas melalui kurva ATR tersebut. Biosensor SPR mampu mendeteksi material berdasarkan parameter indeks bias dan ketebalan material saja. Sehingga pada kajian teoritis dan komputasi, 
sistem ini dapat dimodelkan atau disimulasikan dengan mengetahui beberapa parameter optis material yang terlibat(indeks bias dan ketebalan) pada setiap lapisan, kemudian mendapatkan kurva reflektansinya melalui perhitungan komputasi. Pada penelitian ini sistem biosensor SPR menggunakan konfigurasi Kretschmann seperti yang ditunjukkan pada gambar 3 dengan susunan lapisan adalah prisma/ Ag/graphene/gelatin/udara. Sudut $\theta_{\mathrm{i}}$ and $\theta_{y}$ adalah sudut datang dan sudut bias, $k_{z}$ komponen vektor gelombang pada sumbu- $z$, sedangkan $d$ ketebalan tiap lapisan/layer. Pada konfigurasi ini, nilai indeks bias masingmasing layer diperoleh berdasarkan referensi yaitu indeks bias dari prisma BK7 adalah $1.51^{[12]}$, lapisan tipis $\mathrm{Ag} 0.13455 \mathrm{~d}+3.98651 i^{[13]}$, grapheme $2.5748+1.4935 i^{[14]}$, gelatin $1.383+0.1243 i^{[15]}$ dan udara $1.00^{[16]}$ untuk panjang gelombang $632.8 \mathrm{~nm}$. Tebal lapisan tipis Ag adalah $40 \mathrm{~nm}$, tebal gelatin $20 \mathrm{~nm}$
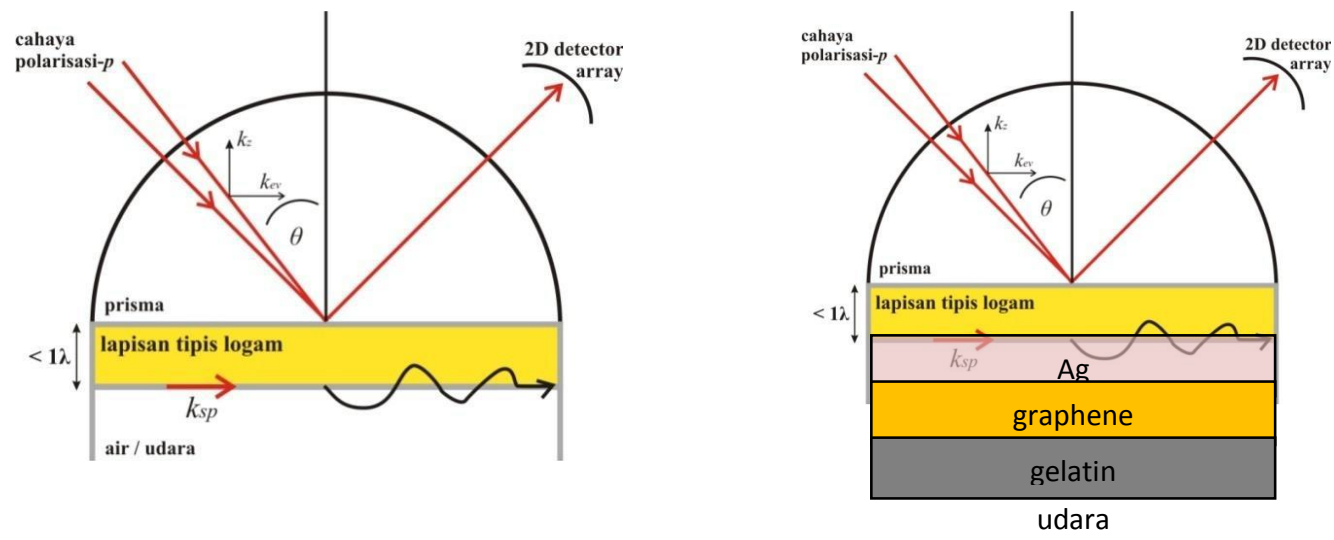

Gambar 3. (color online) Sistem SPR konfigurasi Kretschmann

(a) Konvensional (b) dengan penambahan graphene

Sedangkan kurva ATR diperoleh melalui persamaan Fresnel ${ }^{[17]}$.

$$
R=\left|r_{i j k}\right|^{2}=\left|\frac{r_{i j}+r_{j k} e^{2 i k_{j z} d_{j}}}{1+r_{i j} r_{j k} e^{2 i k_{j z} d_{j}}}\right|^{2}
$$

dengan

$$
r_{i j}=\frac{k_{i} \varepsilon_{j}-k_{j} \varepsilon_{i}}{k_{i} \varepsilon_{j}+k_{j} \varepsilon_{i}}
$$

$r_{i j}$ adalah reflektivitas permukaan antara medium $i$ dan medium $j . k_{i j}$ adalah komponen vektor gelombang yang tegak lurus permukaan, $k_{x}$ adalah komponen vektor gelombang sejajar dengan permukaan, sedangkan $d_{j}$ dan $\varepsilon_{i}$ adalah ketebalan lapisan ke $j$ dan tetapan dielektrik lapisan ke $i$

Sedangkan perhitungan sensitivitas biosensor SPR diperoleh melalui persamaan [18]

$$
S=\frac{\Delta \theta_{\mathrm{pq}}}{\Delta \mathrm{n}}=\frac{\theta_{\mathrm{sq}}\left[\varepsilon_{d}+\Delta \varepsilon_{d}\right]-\theta_{\mathrm{xp}}\left(\varepsilon_{d)}\right)}{\Delta \mathrm{n}}
$$

dengan $\Delta \theta_{s p}$ adalah selisih sudut SPR, $\Delta n$ adalah perubahan indeks bias dan $\varepsilon_{d}$ adalah tetapan dielektrik bahan dielektrik . Nilai peningkatan sensitivitas biosensor SPR dibandingkan dengan biosensor konvensional ${ }^{[19]}$. 


$$
\Delta S=\frac{s_{\text {gaph }}-s_{\text {liwa }}}{s_{\text {lisa }}} \times 100 \%
$$

\section{HASIL DAN PEMBAHASAN}

\section{Kurva ATR Sistem SPR dengan konfigurasi tiga lapisan (Prisma/lapisan tipis Ag/udara)}

Pada sistem SPR, keberadaan bahan deteksi ditunjukkan dari adanya pergeseran dip pada kurva ATR (kurva reflektansi) terhadap dip kurva ATR sebelumnya. Jika pada sistem SPR konvensional yang belum melibatkan bahan analit, dip terjadi pada sudut tertentu maka jika kemudian sistem SPR tersebut melibatkan bahan analit (gelatin babi) maka terjadi perubahan indeks bias pada lapisan dielektrik di bawah lapisan tipis logam Ag sehingga terjadilah pergeseran dip yang ditunjukkan mealui kurva SPR seperti pada gambar 4 . Berdasarkan gambar 3 dip pada sistem konvensional (Prisma/Ag/udara) terjadi pada sudut SPR $69.4^{0}$ sedangkan ketika terlibat gelatin babi, maka dip bergeser ke kanan yaitu pada sudut $69,93^{\circ}$. Pada penelitian ini digunakan dua variasi indeks bias gelatin yaitu $1.383+0.1243 i$ serta indeks bias 1.254 . Nilai reflektansi untuk ketiga kurva relatif hampir sama yaitu 0.1076 (biru) dan 0.1094 (hitam).

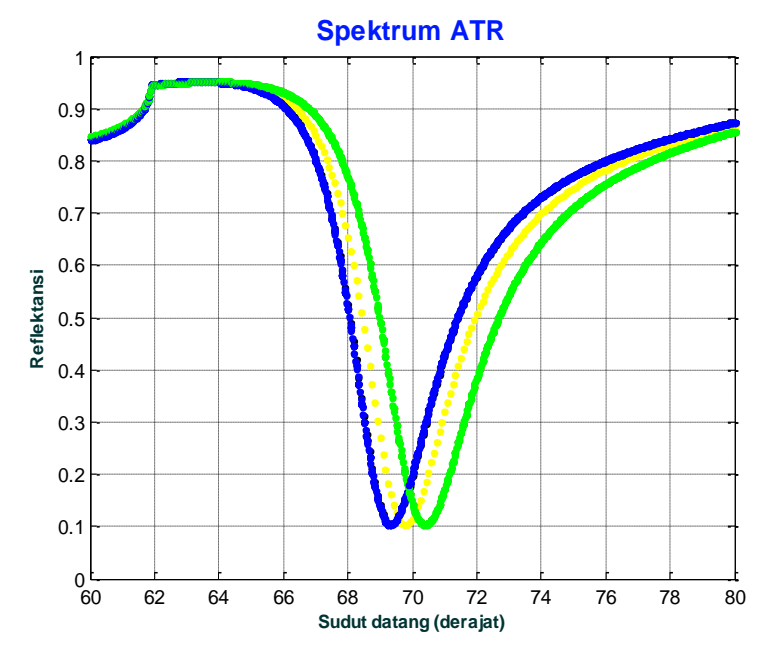

Gambar 4. (color online) Kurva ATR sistem SPR dengan konfigurasi P/Ag/Udara (biru), konfigurasi P/Ag/gelatin babi/udara (kuning $\mathrm{n}=1.383+0.1243 i$ dan hijau $\mathrm{n}=1.354$ ).

\section{Kurva ATR sistem empat lapisan dan lima lapisan dengan keterlibatan graphene}

Keterlibatan lapisan graphene pada sistem SPR yang bertujuan untuk mendeteksi keberadaan gelatin babi (Prisma/Ag/graphene/gelatin/udara) dapat dilihat melalui adanya pergeseran dip kurva ATR gambar 4 dibandingkan dengan kurva ATR untuk sistem konvensional empat lapisan (Prisma/Ag/gelatin/udara). Gambar 5 menunjukkan adanya pergeseran dip semakin ke kanan untuk ketebalan grafik semakin besar yaitu dari $1 \mathrm{~nm}$ sampai $4 \mathrm{~nm}$.. Kopling antara evanescent wave dengan surface plasmon polariton terjadi pada sudut datang tertentu bergantung pada nilai indeks bias tiap lapisan yang terlibat dalam sistem biosensor SPR. 


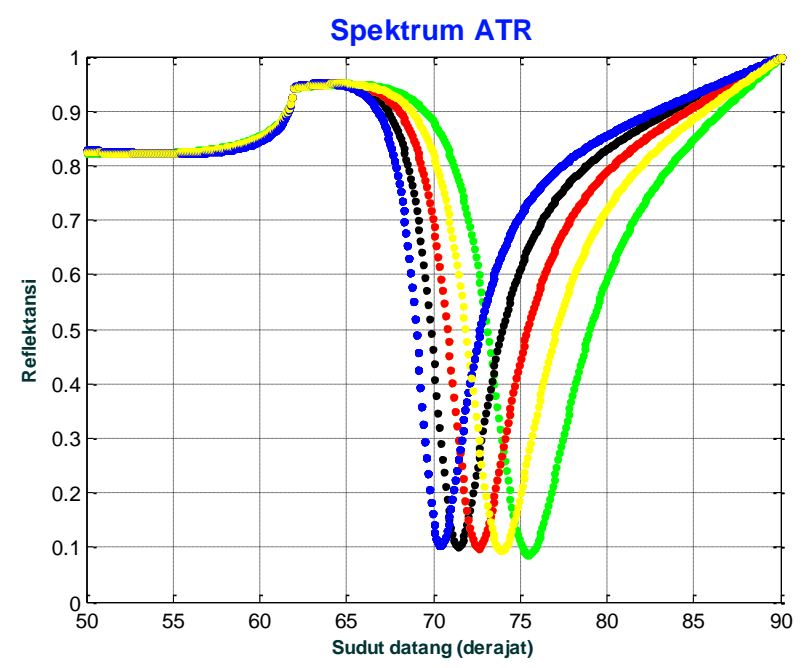

Gambar 5. (color online) Kurva ATR sistem empat lapisan variasi tebal grapheme Prisma/Ag/gelatin/udara(biru),sistem lima lapisaPrisma/Ag/graphene/gelatin/udara dengan variasi ketebalan graphene (hitam=1 nm, merah=2 nm, kuning=3nm, hijau=4 nm).

Jika graphene merupakan lapisan yang ditambahkan di bawah Ag, maka kopling terjadi pada sudut yang berbeda. Di samping bergantung pada indeks bias bahan, kopling yang terjadi juga bergantung pada ketebalan tiap lapisan dalam sistem biosensor SPR. Sehingga seperti yang telah ditunjukkan pada gambar 5, untuk ketebalan graphene yang berbeda, diperoleh dip kurva SPR yang berbeda pula. Sudut SPR pada ketebalan graphene $\mathrm{n}=1 \mathrm{~nm}$ adalah pada $71.93^{\circ}$, pada $n=2 \mathrm{~nm}$ adalah $72.75^{\circ}$, pada $n=3 \mathrm{~nm}$ adalah $74.08^{0}$ dan pada $n=4$ nm pada sudut $75.58^{\circ}$, sehingga semakin tebal lapisan graphene yang terlibat (dalam hal ini sampai $4 \mathrm{~nm}$ ), maka dip semakin bergeser ke kanan yang maknanya adalah semakin besar sensitivitas biosensor tersebut. Sedangkan nilai reflektansi masing masing kurva adalah 0.1094 (biru), 0.1072 (hitam), 0.1029 (merah), 0.098 (kuning) dan 0.08835 (hijau).

Peningkatan Sensitivitas melalui perbandingan kurva ATR sistem tiga lapisan, empat lapisan dan lima lapisan.

Pada konfigurasi biosensor SPR konvensional tanpa keterlibatan gelatin (Prisma/Ag/udara) terlihat dip kurva ATR ada pada sudut $69.4^{0}$ (warna biru). Keberadaan gelatin babi yang dideteksi menggunakan sistem biosensor SPR konvensional (Prisma/Ag/gelatin/udara) ditunjukkan melalui kurva reflektansi atau kurva ATR pada sudut $69.93^{\circ}$ yaitu yang ditunjukkan pada sudut SPR berwarna hitam (gambar 6). Peningkatan sensitivitas yang diukur pada deteksi ini melalui persamaan (5) adalah $\left(69.93^{0}-69.4^{0}\right) / 69.4^{0} \times 100 \%=0.76 \%$ 


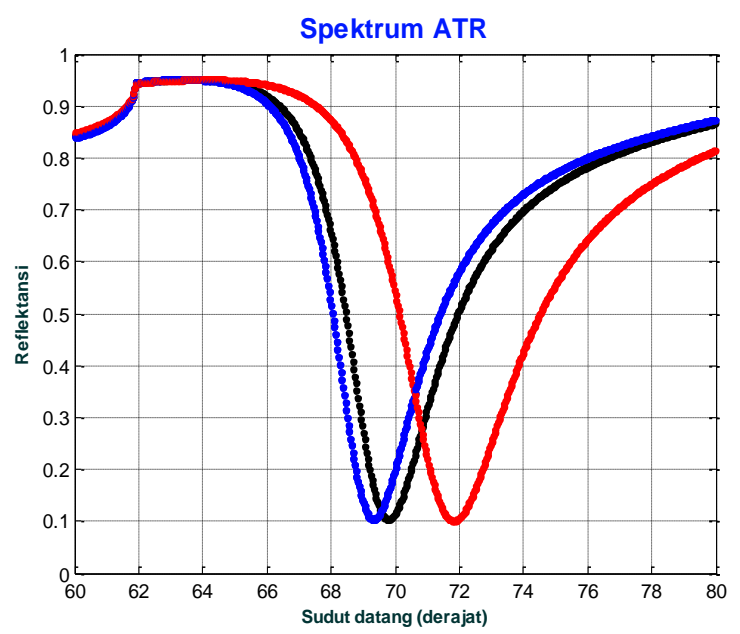

Gambar 6. (color online) Kurva ATR sistem tiga lapisan (biru), empatlapisan (hitam), lima lapisan (merah)

Sensitivitas kurva ATR konvensional tersebut akan meningkat ketika pada sistem biosensor SPR ditambahkan material graphene. Hal ini ditunjukkan pada kurva ATR berwarna merah. Kurva ATR ini dip nya bergeser ke kanan yaitu pada sudut $71.93^{\circ}$. (untuk tebal graphene $1 \mathrm{~nm}$ ). Sehingga peningkatan sensitivitas dapat diperoleh melalui persamaan (4) adalah $\left(71.93^{0}-69.93^{0}\right) / 6993 \times 100 \%=2.86 \%$

\section{KESIMPULAN}

Telah dilakukan kajian pengaruh material graphene terhadap kinerja biosensor SPR untuk mendeteksi gelatin babi melalui pengamatan kurva ATR. Hasilnya menunjukkan bahwa penambahan graphene meningkatkan sensitivitas biosensor sebesar 2.86\%. Sedangkan ketebalan graphene juga berpengaruh terhadap sensitivitas biosensor. Dengan memperbesar ketebalan graphene sampai $4 \mathrm{~nm}$, kurva ATR semakin bergeser ke kanan dan sensitivitas biosensor SPR semakin meningkat pula.

\section{DAFTAR PUSTAKA}

1 Hasnah S H dan Hamdan H, 2013, Experience of Non-Muslim Consumers on Halal as Third Party, Asian Social Science; Vol. 9, No. 15.

2 Redaksi, 2009, 100 persen gelatin masih impor, Harian Republika, Jumat 15 Mei

3 J. Homola, 2006, Electromagnetic Theory of Surface Plasmons Springer Series on Chemical Sensors and Biosensors Method and Application, Springer Ser Chem Sens Biosens, 4, 3-44.

4 Green, R.J., Frazier, R.A., Shakesheff, K.M., Davies, M.C., Robert, C.J., dan Tendler, S.J.B., 2000,"Surface Plasmon Resonance Analysis of Dynamic Biological Interaction with Biomaterials',Biomaterials, 21, 1823-1835.

5 He.L, Musick. M.D, Nicewarner. S.R, Sallinas.F.G, Benkovic.S.J, Natan.M.J, Keating.C.D ,2000, Colloidal Au- Enhanched SPR for ultra sensitive Detection of DNA Hybridization, Journal Am.ChemSoc 122, 9071-9077.

6 Z Salamon, H A. Macleod, and G. Tollin, 1997, Biochim. Biophys.Acta 1331, 131152.

7 Sharma A K, 2013 Plasmonic biosensor for detection of hemoglobin concentration in human blood: Design considerations J. Appl. Phys. 114, 044701 10.1063/1.4816272 
8 Wang, F., Zhang, Y., Tian, C., Girit, C., Zettl, A., Crommie, M., dan Shen, Y.R., 2008, Gate-Variable Optical Transitions in Graphene., Science 320, 206

9 Wardhani D P, 2012, Kajian Awal Identifikasi Perbedaan Gelatin Sapi dan Gelatin Babi dengan menggunakan Biosensor berbasis Surface Plasmon Resonance (SPR), Proceeding Seminar Nasional HFI Jateng-DIY.

10 Mayasari,2013, Kajian Fenomena Surface Plasmon Resonance (SPR) Pada Biosensor SPR dengan Menggunakan Material Graphene, Skripsi FMIPA Universitas Gadjah Mada Yogyakarta.

11 Kretschmann E and Raether H 1968 Radiative Decay of Non-Radiative Surface Plasmons Excited by Light. Zeitschrift Naturforsh 23 A 2135-2136.

12 Wang, K., 2010, Refractive Index of Schott N-SF10, website: http://www.filmetrics.com/refractive-index-database/Schott $+N-S F 10$, diakses tanggal 6 Februari 2012.

13 Johnson P B and Christy R W 1972 Optical Constans of The Noble Metals Phys Rev B 6 No 12.

14 Gray, A., Balooch, M., Allegret, S., Gendt, S.D., dan Wang, W.E., 2008, Optical Detection and Characterization of Graphene by Broadband 64, Spectrophotometry. Journal of Applied Physics, Vol. 104, pp. 053109-053109-8.

15 H. Ding, J.Q. Lu, K.M. Jacobs, X.H. Hu, 2005, "Determination of Refractive Indices of Porcine Skin Tissues and Intralipid at 8 Wavelengths between 325 and 1557nm", Journal of the Optical Society of America A, 22, 1151-1157.

16 Wu L, Chu H S, Koh W S and Li E P 2010 Highly Sensitive Graphene Biosensors base on Surface Plasmon Resonance, Optics Express 1814 pp13143.

17 Rather H 1986 Surface Plasmons on Smooth and Rough Surfaces and Gratings Berlin: (Springer-Verlag.)

18 Verma R, Gupta B D and Jha R 2011 Sensitivity enhancement of a surface plasmon resonance based biomolecules sensor using graphene and silicon layers Sensor and Actuators B: Chemical 160 623-631

19 Adhib M and Abraha K 2011 Enhancement of sensitivity in Surface Plasmon Resonance Biosensor Using graphene materials: A theoretical prediction Proceeding of the 3rd International Conferences And Workshop On Basic And Applied Sciences Bandung. Preprint 